\title{
Europe as an Idea, Will, and Profanation
}

\author{
Szymon Wróbel \\ University of Warsaw, Warsaw, Poland
}

\begin{abstract}
In the paper, the author reflects on Europe as an idea, will, and profanation. He argues that Europe has never crossed the threshold of sheer imagination, i.e., it has never been realized and it is for this reason that it remains a fantasy haunting the modern politics. The phantasm of Europe-the author claims-turned out to be too weak to allow for the translation of the symbolic into a material dimension of Europe. The author ponders upon the reasons of this weakness to conclude that Europe is not only devoid of imagination, but it is also devoid of will (power) in its preference of the forms of as-if existence (a type of le bovarisme) which exercise the ability to imitate and to consider one as a different self. Following Agamben, the author arrives at the conclusion that the only remaining way of thinking about Europe is in terms of profanation whereby the contents of what was previously ascribed to the realm of the sacred are now accessible to all within the community. Yet, without desecration, the original phantasm of Europe would remain unchallenged and it would resist any attempts of its reconfiguration. Profanation should therefore be conceived as the necessary solicitation in order to create and construe a sort of "anti-device" or "anti-Europe". Such despoliation of Europe restores the otherwise lost child's seriousness, the seriousness observed in children playing war games. Transformation of Europe's institutions (devices or social dispositives) into play is about the only way to lift the burden it has become, in the time when the Europeans have already learned that their achievements no longer constitute a proprium, in other words, Europe no longer has the authority to claim ownership of its achievements/property.
\end{abstract}

Keywords: Europe, fundamental phantasm, the ungovernable, seizure, primal scene, will, profanation, idea, play

\section{Idea}

Europe has never crossed the threshold of an idea and threshold of its imaginary; it has never reached the day of its fulfilment and that is why its phantasm haunts the current political situation of the world. The moment of European phantasm's failure to be realized and fulfilled is the moment of its constant manifestation in our words and desires. When I write "a phantasm" and put it in front of the word "Europe", I am not offending Europe because there is nothing depreciating in the word "phantasm"; I especially do not mean the state of dissatisfaction and hallucinatory reaction to this state. I rather have in mind an "idea" (a concept, Vorstellung), which gives our desires material coordinates, i.e., provides a script according to which the subject can achieve fulfillment not as a postulate but also as a citizen of the particular place and time (Žižek, 2008). Hence, a phantasm constitutes a possibility of rewriting and retranslating the symbolic dimension of Europe to the material dimension. I claim that the phantasm of Europe has proved to be too weak for such a translation to be produced. In this text, I ponder on the reasons for this feebleness.

Szymon Wróbel, professor, Institute of Philosophy and Sociology of Polish Academy of Sciences, Faculty of Artes Liberales, University of Warsaw, Warsaw, Poland. 
Alexandre Kojève, a philosopher who held important positions in the French government, published in August 27, 1945, an essay entitled 'L'Empirelatin. Esquissed'une doctrine de la politiquefrançaise/Outline of a Doctrine of French Policy". Kojève (1945) suggested that France should play a leading role in a "Latin Empire" which would link economically and politically three great Latin nations: France, Spain, and Italy, in consultation with the Catholic Church whose tradition it would take over, at the same time, opening itself to the Mediterranean. According to Kojève, protestant Germany, soon to become the richest and most powerful nation in Europe, would inevitably have extra-European temptations and would turn towards a formation in the shape of an Anglo-Saxon empire.

Philosophers, such as Kojève write about a fundamental unity of "mentality" of the Latin Europe, about its "deep structure" revealed through the "art of free use of time which is the source of art in general", and about the "aptitude for creating this 'sweetness of living', which has nothing to do with material comfort", obviously devoted themselves to dreaming about the world and "form of life" which haunted our dreams but were unable to describe the days of labor of a common European: productive and unproductive, material and immaterial, living and dead, registered (white) and unofficial (grey/black). Philosophers were not able to go beyond the phantasm of Europe and transform it into will, hence today we are only dealing with a despoiled orthodoxy of the image of Europe. This phantasmic mentality of Europe, whose ingredient was supposed to be "the sense of beauty coupled with a distinct sense of restraint", allowing for the transformation of ordinary, middle-class prosperity into "the sweetness of life", to lift it to the level of "joy of life" is only a bad dream humanity with unfulfilled desires, humiliated during the day and dreaming at night, a humanity depoliticized and deposited in the form of an impotent phantasm named "Europe".

Europe has never existed and we are losing hope that it will ever come into being. Surely, after the fall of communism, one could get the impression that the West was fascinated by the disintegration of "ideology" in Eastern Europe; on the other hand, the East of Europe, which was never a part of the Latin Empire, became fascinated by the integration of neoliberalism in the West. West and East of Europe seemed to be gazing at each other as if they were looking at each other's crooked mirror images: The East saw in the West its distant ideal, whereas the West perceived in the East new energy which could revive its declining values and its self-doubting, liberal democracy. Today, however, it is hard to talk about a mutual fascination, one could rather talk about a mutual disrelish and disappointment, gradually transforming into a rise in passive, sad affects dormant both in the expanding populations of the precariat as well as the horrified elites which isolate themselves. Does that mean that not only there has been no Europe but also that there has been no common phantasm of "Europe"?

Paradoxically, the process of disillusionment coincided in time with the process of formal integration. Naturally, Kurt Biedenkopf, Bronisław Geremek, Krzysztof Michalski, and Michel Rocard were right when they wrote that "It is not the borders which define the cultural space of Europe; it is rather the cultural space that defines Europe as a geographic space, and which in turn remains open" (Biedenkopf, Geremek, Michalski, \& Rocard, 2004, p. 18). This openness conceals within itself a fascinating and hypnotic element, an element of material indetermination, because it signifies that one is not European only because one happened to be born in Paris or London; one only becomes a European through a certain way of life. The phantasm of Europe concealed in itself the promise of choice and freedom; it gave hope that since its naked life assumes the form of "art of free use of time, which is the source of art in general", we would acquire the noble and joyful figure of a cosmopolitan citizen of Europe. 
This openness, however, did not bring "the sweetness of living" but a regime of never-ending work and efficiency of the cognitive capitalism, turbo-capitalism calling us to ever more effective regimes of discipline, all the more perfidious because they purport to stand for freedom, emancipation, and liberation. The members of Reflection Group were still writing with hope and anxiety:

70 million people-new citizens of the European Union—and many of them have experienced a few dozen years of communist enslavement-are attached to the ideas and values which are marked by the experience not known to former citizens of the Union. (Biedenkopf et al., 2004, p. 19)

Today, we know that these 70 million people, scarred by communism, have dispersed throughout the opulent and rich regions of Europe mainly so that the opulent and rich citizens of the Latin Empire could cultivate "the sense of beauty coupled with a distinct sense of restraint" as well as the "art of free use of time which is the source of art in general". The rest has no time for decadence and restraint.

The question about the European phantasm was well diagnosed formally (though not materially) by Jacques Derrida and Jürgen Habermas in the widely discussed and commented text February 15, or What Binds Europeans Together: A Plea for a Common Foreign Policy, Beginning in the Core of Europe:

Insofar as Christianity and capitalism, natural science and technology, Roman law and the Code Napoleon, the bourgeois-urban form of life, democracy and human rights, the secularization of state and society have spread across other continents, these legacies no longer constitute a proprium. The Western form of spirit, rooted in the Judeo-Christian tradition, certainly has its characteristic features. But the nations of Europe also share this mental habitus, characterized by individualism, rationalism, and activism, with the United States, Canada, and Australia. The "West" encompasses more than just Europe. (Derrida \& Habermas, 2003, p. 294)

Surely, the accomplishments of Europe, i.e., its phantasm, no longer constitute a proprium, that is the deposit and property of Europe. Yet it is so not because they have become widespread, but because they have dispersed and in this sense have annihilated themselves.

Habermas and Derrida do not talk about material conditions of Europe's existence-they talk about its schematic phantasm, that is why they only supply a formal diagnosis, not a material one. Although Habermas and Derrida do undertake an attempt to enumerate the qualities of which the European phantasy is composed, they do not discuss the conditions of its fulfillment, and neither do they ask about the subject of this fantasy, that is, they do not ask: What part of humanity can become the political subject of this fantasy? They do not ask about those who are too poor to be given loans and too numerous to be eliminated. Slavoj Žižek is right when he writes that the answer to the question about who is written into the phantasmic narration as a fantasizing subject is "far from obvious" and not only because European achievements (that is its phantasm) no longer constitute its exclusive proprium.

There is no relationship between a phantasmic reality of the subject and its symbolic identity. "[E]ven when the subject himself appears within his narrative, this is not automatically his point of identification" (Žižek, 2008, p. 6). Fantasy in a psychoanalytic approach does not simply realize desire in a hallucinatory way: Rather, its function is to constitute our desire and provide its coordinates; that is, it literally "teaches us how to desire". Žižek emphasizes that desire is always the desire of the other and draws the conclusion that imagination understood phantasmically always involves an impossible gaze, the gaze by means of which the subject is already present at the act of his/her own conception. 
On the list of Habermas and Derrida, we can find such eccentric inventions as: secularization of the society, belief in the possibilities of the state, skepticism towards the market and technical progress, attachment to the welfare state and solidarism, and renunciation of the death penalty. We do not know, however, if this is our wish list, or whether this is our list of nightmares which only plague us in the moments of greatest fear of the future and its indeterminacy. The "Europe" invention should therefore be treated as a kind of device, a mechanism (dispositive), i.e., a heterogenic ensemble which contains discourses, institutions, art, architecture, regulations, precepts, administrative laws, scientific statements, hopes, and philosophical, moral, and philanthropic enquiries; in short, a set of discursive and non-discursive elements which can serve very different purposes and very diverse subjects. They can fall victim to "abduction" (détournement), capture, hijacking, and introduction onto another scene with other actors. Perhaps more daring than us, capable of using the phantasm to translate what is symbolic into what is real.

\section{The Device of Anti-Europe}

Hence, I endorse the construction of an anti-device, an anti-dispositive: Anti-Europe. Yet what does that mean? To answer this question, we must briefly consider the very concept of the device (dispositifs). The term "dispositive" appears in Michel Foucault's last major book, Histoire de la Sexualité, and more specifically in its first volume, entitled La Volonté de Savoir, first published in 1976. "Dispositif de sexualité" is the title of one chapter; however, in the pages of the work, it appears barely a dozen times and refers to the processes of social subjugation of sex:

[...] from the eighteenth century onwards, [strategic groups of social phenomena-ed. author] form in connection with sex specific devices [dispositifs] of knowledge and power (Foucault, 1979 [1976], p. 124). In a series of Foucault's lectures at Collège de France in 1975-1976, entitled Society Must Be Defended, this concept appears twice and it basically means "relation of domination. (Foucault, 2003, p. 17)

The most serious comments concerning the concept of "device" (dispositive) are: Giorgio Agamben's text titled What is an Apparatus? (Agamben, 2009) and a short, only three-paragraphs-long statement of Foucault in 1977, reproduced in the magazine Ornicar edited by people associated with the Department of Psychoanalysis of the University of Paris VIII at Vincennes, mainly the co-founder of the magazine, and an interview with Foucault, Jacques-Alain Miller, Jacques Lacan's son in law. Foucault says in this interview that he is trying to designate with help of the dispositive (dispositifs), "thoroughly heterogeneous ensemble consisting of discourses, institutions, architectural forms, regulatory decisions, laws, administrative measures, scientific statements, philosophical, moral and philanthropic propositions in short, the said as much as the unsaid. [...]" (Foucault, 1980, p. 194).

Secondly, what Foucault means by dispositive is "precisely the nature of the connection that can exist between these heterogeneous elements", as a result, a discourse may

figure at one time as the programme of an institution, and at another it can function as a means of justifying or masking a practice which itself remains silent, or as a secondary re-interpretation of this practice, opening out for it a new field of rationality. (Foucault, 1980, p. 195)

Thirdly, and finally, by dispositive Foucault understands a strategy, "a sort of - shall we say-formation which has as its major function at a given historical moment that of responding to an urgent need" (Foucault, 1980, p. 196). These three meanings of the word "device" (dispositifs)—-"heterogeneous ensemble", "the very nature of 
the connection", and "type of strategic political formation"-determine the importance of the intellectual and political centrality of the concept. I repeat: When I call to dismantle "the system of domination" called "Europe", it means that I urge to invent another "device" (dispositive) of Europe. The dismantling of Europe meant dismantling the heterogeneous system, i.e., the set of elements calculated by Derrida and Habermas-the European proprium, changing the nature of the connections between these elements in the other set (system), and finally dismantling the political strategy managing the merger of these elements.

Giorgio Agamben, making the "device" the key concept of Foucault's philosophy, equating it with universals, draws attention to three, different from the ones calculated by the author of the La volonté de savoir, semantic tropes contained in this concept: (1) legal significance-the part of the sentence, which results in a legal decision; (2) technical-the way of ordering a mechanism; and (3) military-the totality of all the measures ordained for the implementation of a plan. Again, in this context, the dismantling of the "device" (dispositive) of Europe would mean separation from the curse of the mission of Europe-the mission to civilize the world, and the restoration of its measures to implement this plan-to liberate it from the position of an impotent, apathetic, depressed, and nihilistic subject. Let us state it clearly: Human in the paradigm of the dispositive becomes a being that organizes and is organized at the same time. Humans are here called to organize themselves and manage their destiny. Human is a being capable of not existing without the proliferation of devices and living only in and from the multitude of dispositives. Hence, the only political option is not so much building a phantasm of going beyond the paradigm of "device" (dispositifs), but building a new "device" (dispositifs).

Furthermore, for this reason, I claim that something which could prove useful in understanding the meaning of "project", "device" (dispositifs) of "Europe" is the category of "capture" or "kidnapping" (détournement), also known as la perruque developed by the French Situationists, mostly Guy Debord. The procedure of capturing, in a way similar to satirical parody, is trying to use the old, already existing cultural and historical material, as if employing it at a new job (de Certeau, 1988, p. 165). Hence, "capture" (détournement) is the work of retrieving objects for unknown purposes (not necessarily original), objects appropriated by the media, the market, para-politics, monetary exchange; appropriation experienced today in the form of universal coercion to communicate the project, "device" (dispositifs) of "Europe", in my understanding, should indeed be captured and kidnapped, stolen, and used for innovative new goals.

The use of this technique leads straight to writing a praise of poaching, deception, humor, roguishness, art of trickery, and art of reversing the balance of forces, aiming to ensure that the weaker argument becomes stronger, the art of a coup, finally an incentive to find infinite joy of discovery in everyday life, and the refusal to give the current state of affairs legal status. Situationist practices-whether of Raoul Vaneigem or Guy Ernest Debord (Vaneigem, 1983; Debord, 2014)—are the art of overturning the order of life. The art of walking around the city as an art of wandering, the art of the use of language as art of poaching on books and re-citing the old tropes in constantly changing places, and finally the art of practice of beliefs contesting the "political beliefs" served to us like consumer goods and therefore the art of desecrating the façade of the theater of ostentatious advertising and promises of politicians who appropriate the old theological techniques of ancient demagogues - these are domains, lands, and territories, in which the game of birth is taking place, and maybe even the establishment of a new life, of a new "device" (dispositifs) of "Europe".

Leszek Kołakowski, in his text Czy może Europa zaistnieć? (Can Europe come into existence?), writes in a satirical mode: 
I once asked a friend in Brussels, if Belgians existed at all, or whether there were only Flemings and Walloons. He said that there is always a handful of Polish Jews, who are neither Flemings nor Walloons, so they must be Belgians. (Kołakowski, 2002)

Kołakowski's joke carries an ambiguous question: Is the set of candidates for the European prototype not, accidentally, an empty set? Kołakowski openly encourages to undertake the work of reflection over the status of the phantasm of "Europe". Similarly, Rudolphe Gasché (2009), intending to interpret the phantasm of Europe, to which he referred to as "philosopheme", called us to intellectual, and especially phenomenological battle (labor), whose task would be to problematize the very notion of "Europe"-make it more of an aporetic structure, questioning the subjectivity of those who "know exactly" what Europe was, is, and will be, and who take not only the place of the subject who is said to know, but who also stand stubbornly in the very center of the hegemonic force of the phantasm of Europe. This phantasm proves to be in this incarnation only a symbol of homogenous force and domination of the indexed subject over the rest of the world.

If Europe is not only a name of a certain empty, meaningful, and exclusive geographic region, in which one leads a refined spiritual life based on the joyful spending of free time, then it must constitute a "spiritual configuration" from which we get free ourselves, learn not to desire it, like any phantasm, which not only lets us reach reality, i.e., simply reach something more than just the original (founding) phantasm of a certain regional tribe. It is not Europe which was abducted, it is Europe which has abducted us and introduced into a sphere of a certain fantasy, from which we can find no escape.

\section{Will}

Europe used to be power. Yet power in politics is violence. Power which is not violence is power which belongs to the language of theology rather than politics. Europe without violence is inconceivable and the phantasm of Europe without power is an empty phantasm. Yet in today's Europe, the state, a formation which is by its nature political, i.e., in the final analysis military, is to be replaced by the economic and social or police administration, which remains in the disposition and in the service of the "society" understood as an assembly of individuals, because it is the individual that in his or her distinctness was supposed to personify and reveal the highest human values. Europe today means not only the empire disunited into nations, but also nations disunited into individuals. Europe today is the Tower of Babel. In this tower, the liberal "state" administration is supposed to be deeply peaceful and pacifist. What does that mean? Well, it means that it is actually deprived of "power" and "will" and as a result of the "will to power"- a motive stimulating to action.

Europe is not only devoid of imagination, but also lacks will. This has long been anticipated by some educated Europeans the likes of Nietzsche who have called this state nihilism, which was either the will to nothingness or the nothingness of will, or finally a form of quasi-being (le bovarisme) - the ability to imitate anyone and the ability to consider oneself someone else than one really is. In this sense, Mrs. Bovary is the first authentic European, incapable of any authenticity.

Pierre Manent, author of La Raison des Nations: Réflexions Sur la Démocratieen Europe, states that Europe was a great idea only when this idea was supported by force, including military force (Manent, 2007, p. 6). Contemporary feebleness of Europe is also, and above all, a weakness concerning the sovereignty and representation. "But if European quietism presents a vivid contrast to American activism", writes Pierre Manent, "the two are nonetheless versions of what one might call 'democratic empire" (Manent, 2007, p. 6). Europe for Manent used to be humanity's central agency and the "democratic empire" in its European variety has set itself 
apart by separating democracy from the nation and by building kratos without demos. It seems that Manent's sadness is deepened not only by the awareness of liberalism's inflation, but also by the fall of the "Europe" project. Europe is no longer power. Europe is even less than kratos without demos. Europe is typified by underlining democracy though its results, which invalidate and hinder the functioning of a sovereign country and a constituted people. Democracy in Europe turns against the last difference, a difference which is anthropologically fundamental: superiority of the political over the social. For Manent, the basic condition of equality of condition disappears, which is-according to Tocqueville-the basic condition of democracy: the political form.

We ask, therefore, not only when Europe lost its fantasy, but also when it lost its will. Manent's reply is blunt: Europe has depleted itself when it abolished death penalty and withdrew from universal military service. Abolishing the death penalty was a symbol of the fall of sovereignty and the political; abolishing the universal conscription became a symbol of the fall of the idea of "an armed citizen". In Europe, this ushered the era of an incompetent, disarmed citizen. Only America still understands the notion of sovereignty and the right to sovereign defense in the face of death. Owning a weapon, there is a manifestation of this right. Having experienced the totalitarian regimes, Europe has become depleted, just like Athens after the Peloponnesian War and like Rome once Caesar had crossed the Rubicon.

Romans, especially in Machiavelli's reading of Livy's history, brought to perfection the territorial expansion linked with the ability to convert barbarians into citizens (Machiavelli, 1513-1517/2004), the British Empire brought to perfection the imperial fantasy based on trade, while Americans turned free trade into the main fetish of the civilized world. What has the Latin Empire done for the world? Well, it invented a citizen, who could cultivate in himself "a profound sense of beauty generally [...] associated with a very distinct sense of proportion" and "that art of leisure which is the source of art in general" (Kojève, 1945, p. 15). The Roman Republic minimized the inconvenience of territorial expansion with regards to trade, the British Empire could use trade itself to the greatest benefit; the Americans force whole swathes of humanity to accept exchange without limitations.

Europe still tempts with luxury: a human cultivating the "art of free use of time which is the source of art in general". Tourism is surely the future of Europe, and museums, churches, and gardens are its greatest capital. As a result, four projects or fantasies, based on territorial expansion, work, pure exchange, and seventh day's rest have become depleted or, rather, profaned. The force of the European phantasm stems from the very fact that it is linked with the image of a human at leisure, a human celebrating, a human freed from necessity. Yet the European accomplishments-its phantasms_are not its sole proprium, and the 70 million people, scarred by communism, have launched a search for the phantasm, deeply believing in its existence. Yet the power is depleted. The power is someplace else. Where?

In this very moment, when Europeans are trying, which to people the likes of Pierre Manent is pure madness, to institutionalize the utopian and apocalyptic interpretation of liberal rules, people from beyond the limes discover the reserves of power contained in work and exchange. The time comes for people beyond the limes. It is not the 70 million people, marked with the stamp of communism, functioning today in Europe in the form of disciplined precariat but the populations of Pakistan, India, China, but also Egypt, Syria, Algeria, Morocco, Sudan, Iraq, Yemen, Jordan, Lebanon, and Libya who have gone or are going on the search of the phantasm called "Europe". I repeat: It is not we who have hijacked Europe; it is Europe that has hijacked us. Today, Europe has been "seized"; it has become a device, a dispositive used for work of retrieval of new 
meanings and until now unknown goals, not necessarily fundamental. Europe is no longer for the Europeans. Christianity and capitalism, natural sciences and technology, Roman law and Napoleonic Code, bourgeois lifestyle, democracy and human rights, and secularization of the state and society have all become profaned forever and today we cannot play with them at will without feeling that we are subjects captured in those dispositives, in their machinery or their architecture, i.e., without feeling their sole owners, but at most their momentary users.

I return, therefore, to my fundamental question: What can today the idea of "Europe" stand for? Is it an economic problem, a political crisis, a civilizational catastrophe and spiritual agony, as Marcin Królseems to suggest (Król, 2012)? It cannot be an invigorating return to its teleological beginning-Greece (which is perhaps what Martin Heidegger wanted), i.e., a kind of feeling, mood (Stimmung) linking philosophy and thinking, or all the more so the astonishing exertion of humanity directed at self-understanding (which was perhaps expected by Edmund Husserl), that is a paradigm for all rationality, or even the "head", "headland", or "heading" which defines, releases, arranges, and disposes the prevalence of the individual (which was perhaps what Jacques Derrida wanted), that is the condition and the guarantee of universal idiomaticity and idiosyncrasy, Europe cannot even be a feeling of debt and gratitude, understood as a kind of responsibility for and towards the Other, as was imagined by Rudolphe Gasché (2000).

Europe cannot be a return because a return is marked by erroneous recognition and false identification; it cannot be a model of rationality because this model itself eludes further verification; it also cannot be a "head", which would not conceal its drive for domination; finally, it cannot be a feeling of debt because the debt that we are repaying has long been charged interest rates by banks. As Agamben notes, after years demanding a Europe-Latin Empire which is devoid of banks:

pistis, faith is simply credit, which we enjoy before God and which the word of God enjoys before us until the moment in which we start to believe in it. This is why Paul can say in his famous definition that "Faith is the assurance of things hoped for" (Agamben, 2012)

Banks manage our credit and therefore our faith, which is another name for the future. Europe today is above all financial capitalism and money is nothing more than credit which is given by the banks. By banking on credit and at the same time placing ones faith in it, Europe is simply dealing with the management of human faith. Banks, on the other hand, do not ask about those who are too poor to be given credit and too numerous to be eliminated. So I ask once more: What can the idea of "Europe" stand for today?

\section{Europe as a Certain "Devastation"}

Well, Europe today probably is nothing more than "ravaging", described astutely in the prose of Winfried Georg Sebald. "The shadow of night is drawn like a black veil across the earth", we read in The Rings of Saturn,

and since almost all creatures, from one meridian to the next, lie down after the sun has set $[\ldots]$ one might, in following the setting sun, see on our globe nothing but prone bodies, row upon row, as if levelled by the scythe of Saturn—an endless graveyard for a humanity struck by falling sickness. (Sebald, 1998, p. 90)

Sebald's studies on the skull of Thomas Browne, the devastated splendor of the Somerleyton Hall, the provincialism of the seaside town Lowestoft, the liveliness and mortality of herrings, Korzeniowski's multiplied life, iron bridge on the river Blyth and its origins, empress Cixi, fiery red hair of Algernon Charles 
Swinburne, a visit in Middleton, habits of FitzGerald-Woodbridge's eccentric resident, breeding silkworms in Europe-all of them fill the word "Europe" much more intensively than the great school-bookish sociological analyses.

In the volume The Emigrants (Die Ausgewanderten), we find four moving biographies demonstrating the spiritual geography of Europe. I was touched and deeply impressed by the hotel owner's biography-the self-aware European, Ambrose Adelwarth, guardian of life and fortune of Cosmo Solomon. In Istanbul, he noted:

You climb a bare hillside forever and find yourself once more in a shady valley, enter a house gate and are in the street, drift with the bustle in the bazaar gate and are suddenly amidst gravestones. For, like Death itself, the cemeteries of Constantinople are in the midst of life. For every one who departs this life they say, a cypress is planted. In their dense branches the turtle doves next. When night falls they stop cooing and partake of the silence of the dead. (Sebald, 1996, p. 131)

He is talking about Istanbul here, which is not, despite the efforts of Orhan Pamuk, a geographically European city, but still constitutes an essential metaphor for what is European. For today, Europe is a certain "devastation", that is, "a graveyard affected by humanity's epilepsy"; it is a profanation.

In my view, the sole alternative for the vision of Europe as "an endless graveyard affected by humanity's epilepsy" depicted by W. G. Sebald is the geographic story of Claudio Magris, just as fragmentary but less marked by the pathos of suffering. Especially in the volume of "vagrant essays", as I would prefer to call them, entitled Microcosms, Magris depicts Europe as composed of fragments, details, barely audible places. To Magris, Europe is a café in San Marco, distinguished by its conservative fidelity to the selected culinary and liberal pluralism of its regulars, but it is also Valcellina-a town and municipality in Italy, in the region of Friuli-Venezia Giulia, making a name for itself as "a good province" to which chauvinist hatred is foreign and in which houses stand on steep slopes over chasms, looking down without fear, becoming places which conceal "the sadness of purgatory, much harder to present than hell".

Europe is also lagoons extending over the area of Aquileia, Venice, and Trieste, remembering the "great and empty brightness of summer" where winds reign-the architects of landscape full of imagination-where sirocco crushes rocks, bora sweeps and carries the sand, and a breeze gently builds new formation, and where the lagoons become a symbol of uncertainty of all borders. Europe is also Nevoso-the place of mountain peaks and forests, whose architecture is the architecture of pulpits placed in the trees, spinning the tales of futility of their possession-

Austrian forest first, then Italian, Yugoslavian, finally, Slovenian, it mocks the names and boundaries, it does not belong to anyone; it is rather others who belong to it, at least in so far as you can belong to someone or something [...]. (Magris, 1999, p. 91)

Finally, Europe is a city garden in Trieste, in the middle of which a "black hole" swallows reality, and the garden itself becomes a promise of a real life, i.e., a battle against fossilized culture. In the end, Europe is a river, a Danube, in which history is smoothed and digested by the river and the years, days, months, centuries overlap and mingle over time, like white, smooth pebbles.

The difference between stories of Sebald and Magris is that Sebald writes the most frequently about profaned and immobilized people, who despite always being from one particular place still remain, as a result of the historical process, without a place, they become outcasts, emigrants evicted from a place. Magris, on the 
other hand, usually writes about places which, despite frequently being places inhabited by people with a face, papillary ridges, attire and a set menu, still become places which are subjectless, pure geographies, empty landscapes. Sebald describes people evicted from places; Magris describes places cleared of people. Futility and failure are the main concepts of the novels by W. G. Sebald and C. Magris, they are the common denominator: Their travels across Europe are strolls of witnesses to the fall, but also the strength of revival of people and places, they are tales of the time of geography where mountains and cities, seas and people, animals and rocks, persons and things are born and die, but where a new relationship between a human and a place is established, and where the places themselves become bundles of time which, like the thread of Penelope (or a spider's web), is spun around the Earth.

\section{Profanation}

Giorgio Agamben, in his text entitled The "Latin Empire" Should Strike Back, returns to the phantasm of the union of the countries of southern Europe sketched out by Alexandre Kojève and quoted in the introduction (Agamben, 2013). "Besides the Slavo-Soviet Empire of the Orthodox tradition and the Protestant-inspired Anglo-Saxon, and perhaps the Germano-Anglo-Saxon Empire-writes Kojève-a Latin Empire must be created" (Kojève, 1945). Agamben claims that the Southern Europe could constitute a counterweight to the dominant role which Germany has secured for itself in European Union. "This Europe that strives to exist on a strictly economic basis, abandoning all true affinities between lifestyles, culture and religion, has repeatedly shown its weaknesses [...]" (Kojève, 1945).

Surely the fragility of Europe is its distinctive trait. Agamben claims that "there no sense in asking a Greek or an Italian to live like a German but even if this were possible, it would lead to the destruction of a cultural heritage that exists as a way of life" (Agamben, 2013). According to Kojève and Agamben, the political structure which ignores forms of life is destined to disappear.

If we do not want Europe to inevitably disintegrate as many signs seem to indicate it is, it would be appropriate to ask ourselves, without delay, how the European Constitution (which is not a constitution under public law, but rather an agreement between states, either not submitted to a popular vote or-as in France-flatly rejected [by 54.67 per cent of French voters]) can be reconfigured anew. (Agamben, 2013)

Surely there is no one European form of life. Surely there is no point in forcing it through administrative measures. Surely the "democratic empire" in its European variety has distinguished itself by its separation of democracy from the nation and by building kratos without demos. Surely also economic bookkeeping will not replace culture. Surely Belgians do not exist at all, contrary to Flemings and Walloons, and the 70 million people scarred by communism only dream of "art of free use of time which is the source of art in general". I agree with all of that. One should not, however, draw from all these flimsy premises the conclusion that we will be saved by the new phantasm of the return of the Latin Empire limited to France, Italy, and Spain. Unfortunately, this marks the return to thinking in the categories of immunitas rather than communitas. We will no longer become resistant, protected, untouchable, and immune; we must embrace thinking about Europe as munus - a gift. We must rather start thinking in terms of logic of autoimmunization, which in part "consists for a living organism [...] of protecting itself against its self-protection by destroying its own immune system" (Derrida, 2002, p. 80).

Kojève and Agamben also know about this and they disclose this knowledge when they return to money and power and ask who pays for the fantasy of the Latin Empire and who will defend it against people from 
outside of the limes, from outside of the immunitas? If economic union, despite being the sine qua non condition of Latin imperial unity, is not the raison d'être of the Latin Empire, and the final and true goal of the imperial association is a political goal, then the Latin Empire will need an immune system, i.e., an army which is sufficiently powerful to maintain autonomy, even if it will not be interested (which is very improbable) in making dependent and subjugating one of the surrounding Empires.

I ask, therefore, if I have a chance to go beyond my fundamental phantasm named "Europe"? Do we have a chance to think about Europe in non-phantasmal categories? Moreover, what is this primal phantasm apart from the manner in which the subject imagines itself in relation to the desire of the other, which is the reason of his own desire? After all, humans have many fantasies many of which could not be fulfilled throughout the majority of their lifetimes. Jacques Lacan suggests, nonetheless, that only one phantasm-unconscious to most of us-has absolutely fundamental character. This theory refers to Freudian concept of the "primal scene" playing a major role in the constitution of subjectivity and life in general (Fink, 1999). Well, I would like to argue that at present we have no other way of dealing with this phantasm other than subduing it through profanation.

In order to get liberated from the phantasm of "Europe" and all the more the phantasm of "Latin Empire", I would like to use Agamben against Agamben. Strictly speaking: I would like to appeal to Agamben's idea of profanation against Agamben's idea of the Latin Empire. For I claim that as with many other devices which we are currently dealing with Europe, also the device, the dispositive, the structure of the Latin Empire is a profaned device and constantly "hijacked", "seized", "abducted" anew by people from outside of the limes-70 million people scarred by communism and populations from outside of the Latin Empire who together create the modern Euroislam, who have recognized that the achievements of Europe are no longer its proprium.

One should ask in this context if this passivity of the "attractive Europe" (European attractions) and its kidnapping-deterritorialization and abduction (détournement) should be associated with the antique, mythical abduction of Europa, daughter of Agenor, by Zeus in the form of a bull? Europa seduces Zeus. Yet what does that mean? And in what way does Europa seduce Zeus? Why does she seduce him in the first place? Well, Europa exposes herself to the gaze of Zeus and allows him to see her. Europa exposes herself to the danger of being seen by Zeus. Europa refuses to leave the area in which she is experiencing her objectivity, i.e., being the subject of interest (attraction); a sense of being an object of fascination. Zeus's fascination is the awareness of "being nothing" (being nothingness and emptiness) in the presence of a fascinating being-Fullness (absolute). Due to this seduction the gazing subject (the other) becomes aware that he is empty in the presence of the seducing subject. Through seduction, Europa seeks to constitute herself as fullness of being and, moreover, that this being should be accepted by Zeus as the sole absolute.

The result of this fascination and profanation, i.e., rape in the guise of Zeus's seduction of Europa, was surprising and contrary to the one expected and directed by Europa, because its result was the "domestication of Europa". From the rape, Zeus's children were born. Europa's beauty was second to none and until the time of meeting Zeus she led a pleasant, if not idle life. When Europa was profaned by Zeus, whereby profanation here is understood as "domestication", Europe had to take care of household chores and reproduction. This is a very politically incorrect effect, which distances us from the policy of sexual (gender) equality.

According to Agamben, to profane is to bring into common use that which was in the sphere of the sacrum. Sanctifying a thing means to exclude it from the human sphere of influence. Profanation, which serves to give back to the human the ability to use a given thing, purifies it from the prohibitions and meanings which it 
acquired through the act of sanctification. Agamben believes that religion's only task is to keep a distance between the secular and the sacred, and the word "religion" itself does not stem from the word religare-to connect and unify the human with the divine, but from relegere, meaning "the stance of scrupulousness and attention that must be adopted in relations with the gods" (Agamben, 2007, pp. 74-75).

In Latin, profanare means not only to "secularize something" but also to consecrate it, to make it holy. Due to this contradiction, Agamben returns to the ambivalence retained in the notion to which he dedicates much space in his works, i.e., the very word sacer, meaning both saint and damned, devoted to the gods and excluded. Keeping distance between that which is divine and that which is human is necessary to keep the coherence of the religious system, based on the mechanism of sacrifice. Christianity becomes a breeding ground for the parasite-capitalism, which according to Walter Benjamin takes over the functions of religion. In capitalism, the temple is replaced by the museum, into which art, religion and philosophy have taken refuge. The pilgrim is replaced by the tourist. Pornography which is by definition profane and which therefore cannot be profaned appears.

Is profanation possible then in the totally profaned Europe, reduced to the role of museum rooms? The only possible profanation can solely be understood by the encouragement to mount a "counterattack" which is "the restitution to common use of what has been captured and separated in them" (Agamben, 2009, p. 24), thanks to which the Ungovernable (l'Ingovernabile) becomes "the beginning and, at the same time, the vanishing point of every politics" (Agamben, 2009, p. 25). Thanks to the dispositive and counter-dispositive, we can propose a strong thesis on the subject of profaning the dispositive of Europe, which not only amounts to a well-developed and copied gesture of participating or refusing to participate in the capitalist cult of the Tower of Babel or even constant temptation to build spheres of indecency, but simply a never-ending gesture of hijacking, seizure, abduction and transferal of the dispositives to another scene, i.e., the machines and dispositives we find in the world.

Profanation is therefore a result of failing to notice the difference on purpose, replacing that what is done in all seriousness (solemnly) with playfulness (at ease). Without profanation the phantasm of Europe will never be questioned, shaken, and reconfigured. Profanation of Europe is the reconstruction in adulthood of one's lost childhood dignity, dignity with which a child treats playing war. Children's profanations exceed the sphere of religion and affect other "serious" institutions, such as the market, war, economy, or law. To simplify terms, one can state that the transformation of institutions into play (social dispositives) of Europe is the only chance to disarm it, i.e., the only chance for the happiness of the Europeans, who already know that their accomplishments do not constitute a proprium-European property.

If the primal phantasm of Europe defines the relation between the narrowly conceived European subject ("Europe of the Twelve" or currently: the Troika: European Commission, European Central Bank, International Monetary Fund) and the lost object which brings satisfaction (additional sources of financing in form of credit) if the phantasm of Europe is the effect of relations between the European subject and the traumatic experience (from the European Coal and Steel Community, through European Community, Maastricht Treaty, to Treaty of Lisbon) and in a certain sense can be treated as a response to the separation (areas of competences reserved solely for the Union: customs union, monetary union within the Eurozone, possession of the marine biological resources, a common commercial policy), then phantasm so understood is presently nothing more than a wish (einWunsch), a rather naïve wish, just like all wishes, a wish to get out of the sphere of influence of this 
phantasm. "To return to play its purely profane vocation" (Agamben, 2009, p. 77)—to repeat Agamben's statement—and to cease to deposit the European dispositives, this is the political task for Europe.

\section{Instead of the Ending (Searching for a New Course for Europe)}

Jacques Derrida, on the 200th anniversary of the Revolution, in 1989, reflecting on the fate of deconstruction, poses the question about the future course (cap, le capital, la capitale, ordre du capital, tête) of Europe. What course has Europe taken? What course does Europe "enter" nowadays? Derrida seeks "youth of Europe" in its "old age"; after all he embarks on a voyage to its cape. Derrida also claims that the propensity of European culture is "not to be identical to oneself". What does it entail?

Well, it entails not only the "rejection of identity", but "impotence" in all identification, the refusal to speak in first person singular and plural, the impotence in adopting the "form of the subject" otherwise than in the form of one's non-identity or "difference in relationship with oneself" (Derrida, 1991). In the current political atmosphere, when Europe chooses a course for nation state and populism and authoritarianism, I defend the claim that what we are experiencing is the end of "self-proclaimed Europe" understood as the centre, the head, the helm, as the dictate of the European course. I argue that on its new course Europe aims to withdraw from the notion of Europe being a "universal abstraction" thus far being the opposition to the "specific place" on the geopolitical map of the world. I claim also that we are reaching the end of "conceptual Europocentrism", i.e., to the limits not only of geographical but also conceptual terms of "Europe". The term "Europe" ceases to be the home of a rational subject, i.e., the subject of knowledge.

Does this alone entail that we ought to defend-as Rosi Braidotti (2015, pp. 113-135) claimed-the process of "becoming-a-minority Europe", and take the project of a "global European city" nothing but the idea of "Europe the Fortress"? Does the Europe's privilege, the privilege of invisibility, i.e., that of the invisible subject of omniscience, the alleged spirit of the world, disappear in the process of "becoming-a-minority Europe"? In order to answer these questions, I refer to the idea of heterodidactics. In Spectres of Marx, Derrida establishes heterodidactics, i.e., didactics on the brink of life and death. Therein, Derrida calls us to spectral science, science with spectre (Gespenst) away from the ghost (Geist) (Derrida, 1994).

For deconstruction, there is no science other than the science derived from evoking of spirits. Deconstructive didactics is a machine for evoking phenomena. Therefore, I ask: Can spectres teach us how to live? Is a "minority Europe" not a Europe embroiled in heterodidactics? Derrida answers: Only spectres can teach us how to live. Only the spectres of Europe can teach Europe a new course towards life. "To live, by definition, is not something one learns. Not from oneself, it is not learned from life, taught by life" (Derrida, 1994, p. 11). However, if learning to live remains something that needs to be done, it can only happen between life and death, neither in life itself nor in death itself. I am calling for a talk not about an unconditional Europe, but a Europe that conditioned significantly. Perhaps the figure of Europe's ghost is not just one figure among others. It is the hidden figure of all figures. Drawing the contour of Europe means above all sketching the blueprint of its spirit and specters. 


\section{References}

Agamben, G. (2007). Profanations. (J. Fort, Trans.). New York: Zone Books.

Agamben, G. (2009). "What is an apparatus?” and other essays. (D. Kishik and S. Pedatella, Trans.). Stanford: Stanford University Press.

Agamben, G. (2012). Se la forecereligione del denarodivorailfuturo. In la Repubblica.it (1984). Credit, faith and future (A. Garcia-Ormaechea, Trans.). In blogs.publico.qznewz.info (English). Posęnibankierzykradnanaszaprzyszłość (Gloomy bankers are stealing our future, E. Górniak-Morgan, Trans.). Gazeta Wyborcza 2012, 31 March, No. 77 (Polish).

Agamben, G. (2013). The "Latin Empire" should strike back. Retrieved from https://voxeurop.eu/en/content/article/3593961-latin-empire-should-strike-back

Biedenkopf, K., Geremek, B., Michalski, K., \& Rocard, M. (2004). Co łączy. Europę? (What connects Europe?). Gazeta Wyborcza 2004, 11-12 December, No. 290, p. 18.

Braidotti, R. (2015). Nomadic European identity. In P. Gielen (Ed.), No culture, No Europe: On the foundation of politics (pp. 113-135). Amsterdam: Idea Books.

De Certeau, M. (1988). The practice of everyday life. (S. Rendall, Trans.). Berkley: University of California Press.

Debord, G. (2014). The society of the spectacle. (K. Knabb, Trans.). Berkeley, CA: Bureau of Public Secrets.

Derrida, J. (1991). The other heading: Reflections on today's Europe. (P. A. Brault and M. B. Naas, Trans.). Bloomington: Indiana University Press.

Derrida, J. (1994). Specters of Marx: The state of the debt, the work of mourning, and the new international. (P. Kamuf, Trans.). New York: Routledge.

Derrida, J. (2002). Faith and knowledge: The two sources of "religion" at the limits of reason alone. (S. Weber, Trans.). In G. Anidjar (Ed.), Acts of religion. London: Routledge.

Derrida, J., \& Habermas, J. (2003). February 15, or what binds Europeans together: A plea for a common foreign policy, beginning in the core of Europe. Oxford: Blackwell Publishing Ltd.

Fink, B. (1999). A clinical introduction to Lacanian psychoanalysis: Theory and technique. Harvard: Harvard University Press.

Foucault, M. (1976/1979). The will to knowledge: The history of sexuality Volume 1. (R. Hurley, Trans.). London: Allen Lane.

Foucault, M. (1980). The confession of the flesh. In C. Gordon (Ed.), Power/Knowledge: Selected interviews and other writings, 1972-1977 (p. 194). New York: Pantheon Books.

Foucault, M. (2003). Society must be defended: Lectures at the Collège de France, 1975-76. (D. Macey, Trans.). New York: Picador.

Gasché, R. (2000). Feeling the debt: On Europe. In K. Ziarek and S. Deane (Eds.), Future crossings: Literature between philosophy and cultural studies (pp. 125-146). Evanston, Ill.: Northwestern University Press.

Gasché, R. (2009). Europe, or the infinite task: A study of a philosophical concept. Stanford: Stanford University Press.

Kojève, A. (1945). Outline of a doctrine of French policy: Translation of 1945 memo. Policy Review, (126), 3.

Kołakowski, L. (2002). Czy może Europa zaistnieć? (Can Europe comeintoexistence?), "Apokryf” nr 18. In “Tygodnik Powszechny" 2002, No. 43.

Król, M. (2012). Europa w obliczu końca (Europe facing the end). Warszawa: Wydawnictwo Czerwone i Czarne.

Machiavelli, N. (1513-1517/2004). Discourses on the first decade of Titus Livius. In The chief works and others (Vol. 1, A. Gilbert, Trans.). Durham: Duke University Press.

Magris, C. (1999). Microcosms. (I. Halliday, Trans.). London: Harvill Press.

Manent, P. (2007). Democracy without nations?: The fate of self-government in Europe. (P. Seaton, Trans.). Wilmington, Delaware: ISI Books.

Sebald, W. G. (1996). The emigrants. (M. Hulse, Trans.). Frankfurt: Vito von Eichborn GmbH \& Co Verlag KG.

Sebald, W. G. (1998). The rings of Saturn. Frankfurt: Vito von Eichborn GmbH \& Co Verlag KG.

Vaneigem, R. (1983). The revolution of everyday life. London: Left Bank Books and Rebel Press.

Žižek, S. (2008). The plague of fantasies. London: Verso. 